\title{
DEMONSTRATIVE PRONOUNS IN BALTO-SLAVIC, ARMENIAN, AND TOCHARIAN
}

FREDERIK KORTLANDT

1. A reconstruction of the Balto-slavic demonstrative pronouns must be based on a comparison of the Prussian (Pr.), Lithuanian (Li.), and Old Slavic (SI.) evidence. Such a comparison turns out to be more complicated than it might appear at first sight.

The PIE. demonstrative pronoun so, sī, tod is reflected in $\mathrm{Sl}$. $\mathrm{Tz}$, Li. tàs, and Pr. stas. Van Wijk has conclusively argued that the Prussian forms arose from a contamination of sa and ta- (1918: 111). It follows that the suppletive nom.sg. forms so and sá had been preserved in the Balto-Slavic proto-language. Similarly, the stem ono- (ano-) provides suppletive nominative forms for the pronominal stem $i(0)-$ in both Slavic and old Lithuanian (cf. Van Wijk 1918: 116). Since the nom.pl. forms are probably secondary (ibidem: 125), we can assume for Balto-slavic the same distribution here as in the case of so, sàa, to-.

Consider now the following normalized paradigm of the $\operatorname{Pr}$. 3rd person pronoun as it appears in the Enchiridion: 
sg. nom. m. tāns, f. tennāa.

gen. m. tennessei, tennēison.

dat. m. tennesmu, f. tennēi.

acc. mf. tennan, din.

pl. nom. m. tennei, dei.

gen. mf. tennëison.

dat. m. tennëimans.

acc. mf. tennans, dins.

The acc. forms tennan and tennans are evidently based on the stem ono- (ano-), which underlies the nom.sg.

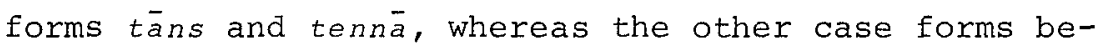
tray an alternating stem $e-, e i-, i-$. This state of affairs is more archaic than the one attested in the flexion of the Li. and SI. 3rd person pronoun, where we find an alternation between $i$ - and io-.

The problem becomes even more complicated if we take the flexion of the Pr. demonstrative pronoun stas into account. If we disregard its use as an article, the paradigm can be normalized as follows:

sg. nom. m. stas, f. stai, n. sta.

gen. m. stessei, f. stessies.

dat. m. stesmu, f. stessiei.

acc. mf. stan.

pl. nom. mf. stai.

gen. mf. stéison.

aat. mf. stēimans.

acc. mf. stans.

For the article the paradigm must be modified as follows :

sg. gen. m. stessei, stēisei, stēison,

f. stesses, stessei, stēisei, stēison.

dat. m. stesmu, stēismu,

f. stessei, stēisei, stesmu, stēismu. 
If we assume that only the first form of every line is original, we arrive at a paradigm which differs from the pronoun in the feminine gen. and dat.sg. forms only. Elsewhere I have argued that this difference is probably old and that we have to compare the article with skt. asyás, asyái < esiās, $-\bar{a} i$ and the pronoun with tásyās, tásyai < tosiās, -āi (1982: 9). This leads us to the reconstruction of three types of demonstrative pronoun in order to account for the Prussian material:

- an anaphoric pronoun to- + ono- (ano-) + e/i-,

- a weak demonstrative so + to- +e/i-,

- a strong demonstrative so + to-.

2. Apart from the pronouns mentioned so far, there is an unmistakable correspondence between SI. cb, Li. šis, and Pr. schis, all of which designate hic deixis. Here again, the details are such that they preclude a straightforward reconstruction of the Balto-slavic paradigm. The slavic word is inflected as a soft stem in spite of the fact that the stem was undoubtedly hard, as is clear from the West slavic reflex s-, not s-. It follows that the formation of the slavic paradigm was probably posterior to the umlaut and that we have to assume that the alternating stem e-, ei-, iwas preserved in early Slavic. This hypothesis also accounts for the aberrant masculine nom.pl. form cun (cf. Vaillant 1958: 383). The gen. and dat.sg. forms $c \in \Gamma o, c \in r A$ and $c \in M o r, c \in H$ suggest that the formation of the new paradigm can be dated between the umlaut and the rise of prothetic $j$-before $e-$, $i . e$. to what I have called the Early Middle Slavic period (1979: 263). If it had been earlier or later, we would expect šeor sije- rather than se-. 
The flexion of Pr. schis is particularly difficult to establish. I am inclined to start from the following normalized paradigm:

sg. nom. m. schis.

gen. m. schissei.

dat. m. schismu.

acc. mf. schan, schien.

pl. nom. m. schai.

gen. mf. schiēison.

acc. mf. schans, schiens.

It is attractive to regard schan, schans and schien, schiens as original masc. and fem. forms, respectively, though the material is too small to substantiate this hypothesis. If it is correct, the paradigm contains three different stems: $\check{s}$ - in the nom.sg. form and in the case forms which have -e- in the paradigms of stas and tāns, ša- in the forms which have -a- in the paradigm of stas, and sie- in the feminine. The initial $5-$ must have spread from ša- to the other stems, as it has in Latvian.

The flexion of Li. Šis is identical with that of

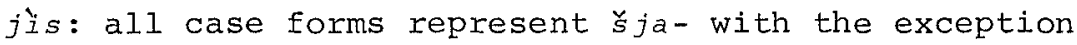

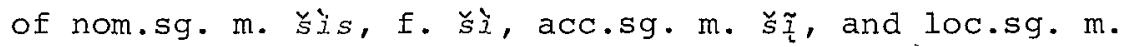
šimè next to šiamè (cf. Dauksa jimè next to jamè). Latvian has probably preserved an archaism in the vocalism of the masc. case forms: dat.sg. ̌̌im, acc.sg. šuo, loc.sg. šimì, ̌sin $\bar{i}$. If this is correct, the vocalism of the East Baltic masc. paradigm is identical with the one which I have proposed for its Prussian counterpart.

Putting the pieces together, we find that the Baltic and Slavic paradigms cannot be reduced to a single set of proto-forms. The Slavic paradigm appears to have originated from a conflation of the PIE. 
particle $k^{\prime}$, Balto-Slavic s'i, with the paradigm of e/i-. The Baltic forms seem to have resulted from the addition of pronominal endings to the same particle, in Prussian apparently with generalization of $s^{i}-$ throughout the feminine. It is therefore probable that the form s'i remained an uninflected particle up to the end of the Balto-Slavic period and was subsequently reshaped on the basis of the inflected pronouns in the separate languages.

3. We have now arrived at the reconstruction of a demonstrative pronoun so, to-, an anaphoric pronoun e-, ei-, i-, a suppletive nom.sg. form in $-n-$, and an uninflected particle śi meaning 'hic'. In addition, there is a sl. stem ovo-, also meaning 'hic', correlating with ono- 'ille', and a stem ino-, meaning 'other' in Slavic and 'real' in Iithuanian and apparently related to PIE. oino- 'one'. The latter word will not be discussed here.

The stem ovo- is probably a slavic derivative of the uninflected PIE. particle $a u$, which is preserved in Gr. ar̃ 'again', aútós 'self', Li. aurè 'there'. It preserved the original meaning 'that other' in Polish, Sorabian, and Slovene, whereas it replaced $s$ - in Serbo-Croat and the contiguous south Slavic dialects (cf. Vaillant 1958: 380). If it can be suggested that śi and $a u$ were correlating particles in Balto-slavic, designating 'hic' and 'istic' and used in combination with a neutral deictic stem, one may wonder if the suppletive nom.sg. form in $-n$-must be derived from a particle meaning 'illic'. This conjecture is indeed supported by the isolated Irish adverb and 'there', which is identical with Arm. and 'illic', cf. Li. añdai 'the other day', Gr. Ẽvn 'the day after tomorrow', 
Ëvণa 'there'. Assuming that Greek substituted the regular deictic element e- for a-, I reconstruct a Balto-Slavic particle an 'illic' which served as a basis for the creation of the $3 r d$ person pronoun.

Starting from a single original demonstrative pronoun (so, to-), a single anaphoric pronoun (e/i-), and three deictic particles (śi, au, an), we can derive the Slavic and East Baltic paradigms in a straightforward way. The main problem which remains to be discussed is the rise of the Prussian forms. I think that the clue to a possible solution is provided by the Armenian system.

Unlike the other Indo-European languages, Armenian possesses three anaphoric pronouns, corresponding to the three demonstrative pronouns:

$\begin{array}{lll}\text { ays 'hic' } & \text { sa' 'is' } & \text { soyn 'idem' } \\ \text { ayd 'iste' } & d a \text { 'is' } & \text { doyn 'idem' } \\ \text { ayn 'ille' } & \text { na 'is' } & \text { noyn 'idem' }\end{array}$

The radical element of the three series is identical with the one of Li. šis, tàs, anàs. As Holger Pedersen has pointed out (1982: 38f), the starting-point of the Armenian development must be sought in the forms $d a$, which represents to-, and ayn, which is the reflex of anio-, Skt. anyá- 'other'. The latter word is a derivative of the proposed particle an, which has been preserved in the adverb and 'there', cf. also ckt. ántara- 'other', Li. añtras 'second'. Thus, we can derive the Arm. system from the one which has been reconstructed for Balto-slavic.

The correctness of this analysis is corroborated by the forms awasik 'voici', awadik, awanik 'voilà'. Pedersen already identified -sik with SI. culb as a derivative in -ko- of PIE. ki (1982: 41). It gave apparently rise to a correlating form anik, which in its 
turn supplied the initial vowel for the creation of a form asik. Similarly, the initial vowel of ast 'here' was evidently taken from and 'there'. The initial part aw- may represent the PIE. particle au. Perikhanian's hypothesis that the forms under discussion are of Iranian origin does not explain the -i- (1966:22). of course, Iranian $h \bar{a} u$ is itself a conflation of so and au. The close resemblance between the pre-Armenian and the reconstructed Balto-Slavic system and the presence of a threefold anaphoric pronoun in Armenian together offer an explanation for the origin of Pr. tāns. This pronoun evidently received its $t$-after the rise of a pronominal stem ane-, anei-, but before the contamination of so with to-. I therefore assume that there was a threefold anaphoric pronoun at an intermediate stage in the development of Prussian. The first step of the development was apparently the creation of a paradigm an, ane-, anei- 'he there'. This paradigm gave rise to the creation of correlating forms te-, tei- and si-, siei-. At the same time, or perhaps earlier, the demonstrative pronoun so, sā, to- gave rise to correla-

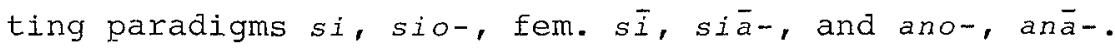
A form tan was probably created on the analogy of an in order to supply a nom.sg. form for the defective paradigm of te-, tei-because neither so nor a provided a suitable basis. When the threefold distinction in the anaphoric pronoun was lost, the stem tan-was generalized as a $3 r d$ person pronoun. A trace of the earlier distribution is found in the substitutive use of stas for tāns, e.g. 75.13-22:

Bhe kai prastan rettīwingiskan auskandinsnan en tennesmu (addex stessie) auskiēndlai bhe semmai éilai wissan ka stesmu (adder tennēi) esse Adam engemmons ast kai tans (adder tennā) dijgi is stesmu gīrbin steison 
nıdruwīngın ısklaltınts ënstan Swlntan Arcan stēison CrIxtıänıskun sausal bhe senpackal polalküts Alnat garrewingl en Noselizen Wessals en podruwisnan twalsmu emnen schlūsilal. Nostan kal tāns (adder tannā) sen wissamans Druwinglmans twaisel potaukinsnas Prabutskan gēiwan senglaaut musīlal "vnd das durch diese hellsame sündflut an jm ersauffe vnd vntergehe alles was jm (oder Jr) von Adam angeborn 1st. Das er (oder sie) ausz der Zal der Vnglaubigen gesondert inn der heliıgen Archa der Christenheit trucken vnd sicher behalten allezert brünstıg $1 \mathrm{~m}$ Geist vid frölıch Inn Horfnung deınem Namen diene. Auff das ex mit allen Glaubigen delner Verhelssung Ewıges leben erlangen moge".

After the generalization of tan- in the anaphoric pronoun, the contamination of so and to- in the demonstratıve pronoun ylelded the regular paradıgm of stas. This development may have started elther in the nom.sg.

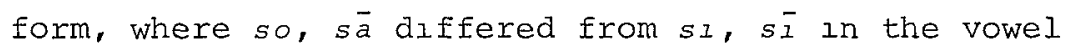
only, or in the acc.sg. form, where ton and $t \bar{a}^{n}$ became tan as a result of the evolution of the vowel system, which created a disturbing homonymy with the pronominal stem tan-. In my view, this homonymy may have been the reason for the generalization of acc.sg. -an, pl. -ans in the forms tennan, tennans, as opposed to nom.pl. tennel, where the vocalism of the original anaphoric pronoun has been preserved. The resulting mixed paradigm provided in its turn the model for the substitutıon of $\breve{s}_{I}$ - for $\check{s}_{a-}$ in the oblique cases of the demonstrative pronoun schis, which preserved the original vocalısm in nom.pl. schal. These analogical changes obliterated the distinction between demonstrative and anaphoric pronouns, the only trace of whlch remains in the feminine gen. and dat.sg. forms of stas, where a consistent differentiation is made between the pronoun 
(5x) and the article (15x).

4. The analysis proposed here offers an explanation for the formation of the Tocharian demonstrative pronoun. If we disregard B samp 'that there', which is obviously a compound of se with the adverb omp 'there', there are three paradigmatic sets: A säm, B su 'that', A säs, B se 'this', A san, B sen 'this here' (I write $-n$ for the anusvāra). The inflected forms are the following:

sg, nom. m. A säm, säs, san, B su, se, sen.

f. A sām, sās, sān, B sāu, sā, sān.

n. A täm, täș, tan, B tu, te, ten.

obl. m. A cam, caș, can, B ceu, ce, cen.

f. A $t \bar{a} m, t \bar{a} s ̣, t \bar{a} n, B$ tàu, tà, tān.

pl. nom. m. A cem, ceș, cen, B cey, cey, cey.

f. A tom, toș, ton, B ton, toy, toyna.

obl. m. A cesäm, cesäs, cesän, B cen, cen, ceyna.

f. A tosäm, tosäs, tosän, B ton, toy, toyna.

A comparative analysis leads to the following reconstruction of the Proto-Tocharian (PT.) forms:

sg. nom. m. se, sä-, f. sa, n. te, tä-.

obl. m. ce, f. ta.

pl. nom. m. cei, f. toü.

obl. m. cens, f. tons.

finals: $-u,-m,-\check{s},-n$.

The extension of the final elements to the plural forms appears to be a recent development.

Lane has connected $-m$ with the medial consonant of S1. Tomor (1961: 475). This is doubtless correct. The other final elements must probably be identified with the three particles which have been reconstructed for Balto-Slavic. The expected reflex of PIE. ki is $-s$ rather than $-\check{s}$, but the alternation with $-s$ in forms 
with another $s$ and the correspondence between $A n \ddot{a} s$ and B ñäs' 'I, me', which can hardly be separated from the particle, suggest a neutralization of the opposition between the sibilants at the end of the word. I therefore assume that $-\breve{s}$ represents earlier $-\dot{s}$. The same particle is found as the $3 \mathrm{rd} \mathrm{sg}$. ending A - s in the present tense of the verb. Simlarly, final -n is found in the corresponding $B$ ending (cf. Pedersen 1941: 142f). An inflected form of the latter particle is attested in the 3 rd $\mathrm{sg}$. sufflxed pronoun $A-n, B-n e$, suggesting an earlier paradigm which is strongly remınıscent of Balto-Slavic: nom. an, acc. anom.

The distribution of $-u,-m$, and $-\check{s}$ does not require any special comments, but the semantic shift of - $n$ is noteworthy. It can be compared with the South Slavic substitution of ov- for s- 'hic'. In the oldest texts, the Sl. stem is only used contrastively: Овъ ... ОВз ог Овъ.. Ннв, Cf. also Polısh ten ... Ów. Similarly, Toch. -n obtained the meaning 'hic' through its contrastive use in juxtaposition with the demonstrative pronoun. The orıginal meaning was preserved in the suffixed anaphorıc pronoun, and also in the indefinite pronoun A san, which is often found in combination with $\bar{a} l a k$ 'other'. It is possible that B omp 'there' is related to Arm. and 'there'. The final - $p$ may be identical with $L_{1} .-p_{l}$ 'at', Gr. Éri 'upon'. The vocalism of the Toch. forms is remarkable. Since PT. $e(A a, B$ e) is the phonetic reflex of PIE. 0 , B se, te developed regularly from so, tod. The same vowel is found before the final $-n$, but not before $-m$, $-\breve{s},-u$, where we find $s \ddot{a}-$, tä-, with $\ddot{a}$ representing PIE. e, 1, but without the expected palatalization of the inltial consonant before an orlginal front vowel. It is therefore probable that we have to start from a 
pronominal stem $e / i$ - and that the addition of $s-$, $t-$ was posterior to the palatalization.

The hypothesis that the pronominal stem e/i-was preserved in early Tocharian is corroborated by the palatalization of the initial consonant in $\mathrm{PT}$. ce (A ca-, B ce), cei (A ce-, B cey), cens (A cest, B cen). If we disregard the palatalization, these forms are the expected reflexes of tom, toi, tons. It follows that there must have been a stem te-with a suppletive nom.sg. form and that the initial consonant of this paradigm was adopted in the demonstrative pronoun. Here the Prussian forms come to mind. On the one hand, the absence op palatalization in nom.sg. se, te and its presence in ce, cei, cens is reminiscent of the reconstructed paradigm tan, te-, tei-. On the other, the discrepancy between the reduced vowel of nom.sg. sä-, $t \ddot{a}$ - from e-, $i-$ and the full vowel of ce, cei, cens from to- has its counterpart in $\mathrm{Pr}$. schis, schan, schai, schans.

I now tentatively reconstruct a PT. anaphoric pronoun äs, $\ddot{a} u, \ddot{a} n$, perhaps with an initial $y-$, obl. cäm in noun phrases, -ne in verb phrases, and a demonstrative se, sen, obl. ce, cen, meaning 'this' when used contrastively with the anaphoric pronoun and designating simple deixis in juxtaposition with adverbial particles. The loss of the expected initial $y$ - is also attested in B ente, A äntāne 'when' < PIE. io-, cf. B intsu, A äntsan 'which'. These forms point to a contamination of io-, e/i-, and an. The vocalism of the latter seems to be preserved in $A \bar{a} n$ 'whom', which is the phonetic reflex of anom.

Thus, we arrive at a reconstruction which strongly resembles the one proposed for Balto-slavic. In both cases we have to start from a demonstrative pronoun 
so, to-, an anaphoric pronoun e/i-, and three deictic particles $k^{\prime} i, a u, a n$. The attested paradigms originated from different kinds of contamination. One may therefore wonder if the feminine nom.pl. form PT. to $\ddot{u}$ (A to-, $B$ toy), which can be regarded as the phonetic reflex of $t \bar{a} w e s$, must be derived from a contamination of $t \bar{a}-$ and au-. I do not think that this is probable. The form is better connected with nom.pl. A śnu of śän 'wife', which points to the spread of -wes as a nom.pl. ending of feminine nouns at an early stage in the development of Tocharian.

University of Leiden

REFERENCES

Kortlandt, F.H.H.

1979 "On the history of the Slavic nasal vowels", Indogermanische Forschungen 84, 259-272.

1982 "Innovations which betray archaisms", Baltistica 18/1, 4-9.

Lane, G.S.

1961 "On the formation of the Indo-European demonstrative", Language $37,469-475$.

Pedersen, $\mathrm{H}$.

1941 Tocharisch vom Gesichtspunkt der indoeuropäischen

sprachvergleichung, Kobenhavn.

1982 Kleine Schriften zum Armenischen, Hildesheim.

Perikhanian, A.

1966 "Une inscription araméenne du roi Artašes trouvée à Zanguézour", Revue des études arméniennes, NS. 3 ,
17-29.

Vaillant, A.

1958 Grammaire comparée des langues slaves II: Morphologie, Lyon.

Van wijk, N.

1918 Altpreussische Studien, Haag. 